\title{
Weed Control in MaIZe With GLIRICIDia INTERCROPPING ${ }^{1}$
}

\author{
Controle das Plantas Daninhas no Milho em Consórcio com Gliricídia
}

TAVELLA, L.B. ${ }^{2}$, SILVA, P.S.L. ${ }^{2}$, MONTEIRO, A.L. ${ }^{2}$, OLIVEIRA, V.R. ${ }^{2}$, and SIQUEIRA, P.L.O.F. ${ }^{2}$

\begin{abstract}
One of the very important components in the organic maize production costs refers to spending on weed control. In this research were assessed the effects of maize hybrids (AG 1051 and BR 205) in an intercropping with Gliricidia (Gliricidia sepium) and mechanical hoeing on weed control. The treatments assessed were: A - maize monocropping + two hoeings (20 and 40 days after sowing); B - maize with one hoeing at 20 days + intercropping with gliricidia sowed after hoeing; $\mathrm{C}$ - maize sowing intercropped with gliricidia at the time of maize sowing + hoeing at 40 days; D - maize sowing intercropped with gliricidia at the time of maize sowing without hoeing; E-monocropping maize without hoeing. In the intercroppings, gliricidia was sowed in broadcast seeding with 30 viable seeds $\mathrm{m}^{-2}$. Maize hybrids did not differ in their effects on weed growth and grain yield. Treatments A, B and C have reduced weed growth, compared to treatments D and E. The highest grain yield was obtained with treatment A and the lowest with treatment E. It was concluded that intercropping maize and gliricidia is not a good alternative for an integrated weed management in maize crops in the conditions assessed.
\end{abstract}

Keywords: Zea mays, Gliricidia sepium, maize yield.

RESUMO - Um dos componentes de grande importância nos custos de produção do milho orgânico refere-se aos gastos com o controle das plantas daninhas. Nesta pesquisa, foram avaliados os efeitos de híbridos de milho (AG 1051 e BR 205) em consórcio com gliricídia (Gliricidia sepium) e capinas mecânicas no controle de plantas daninhas. Foram avaliados os seguintes tratamentos: $A-$ cultivo do milho solteiro com duas capinas (20 e 40 dias após a semeadura); $B$ - consórcio com uma capina aos 20 dias + consórcio com gliricidia semeada após a capina; $C$ - cultivo do milho em consórcio com gliricídia por ocasião da semeadura do milho + realização de capina aos 40 dias; $D$ cultivo do milho em consórcio com gliricídia por ocasião da semeadura do milho sem capinas; Ecultivo do milho solteiro sem capinas. Nos consórcios, a gliricídia foi semeada a lanço, com 30 sementes viáveis $m^{-2}$. Os híbridos de milho não diferiram entre si quanto a seus efeitos sobre o crescimento das plantas daninhas e o rendimento de grãos. Os tratamentos $A, B$ e $C$ reduziram o crescimento das plantas daninhas, em relação aos tratamentos $D$ e $E$. O maior rendimento de grãos foi obtido com o tratamento A, e o menor, com o E. Concluiu-se que o cultivo de milho e gliricidia em consórcio não é boa alternativa para o manejo integrado de plantas daninhas na cultura do milho nas condições avaliadas.

Palavras-chave: Zea mays, Gliricidia sepium, rendimento de grãos.

\section{INTRODUCTION}

Hoeings are the most often used weed control method in the exploitation of various crops of Brazil (Model \& Favreto, 2010). Although an effective method, it is laborious and time consuming, especially if several hoeings must be performed (Chikoye et al., 2004). In addition, hoeings can be difficult to perform in the rain and are expensive. Zárate et al. (2009) have estimated that the cost of hoeing represents $35 \%$ of the cost of labor in a

Recebido para publicação em 10.2.2015 e aprovado em 13.2.2015.

2 Universidade Federal Rural do Semi-Árido, Mossoró-RN, Brasil, <leo_tavella@hotmail.com>. 
maize crop. The weed control with herbicide application is almost always fast, efficient and economical (Silva et al., 2012). However, herbicides are considered, among the chemicals used in agriculture, as the main polluters of soil and water. This pollution results in the impoverishment of fauna and flora and human intake of residues of herbicides by means of the consumption of water and food (Pinheiro \& Rosa, 2008). Furthermore, the use of herbicides favors the growth of weed biotypes resistant to them (Christoffoleti, 2008). Due to the problems posed by hoeing and herbicide to control weeds, several alternative methods are being tested. In one such attempt, Oliveira et al. (2011) have intercropped maize with gliricidia (Gliricidia sepium), a leguminous tree. The intercropping was established by sowing the legume by broadcast seeding, at the time of sowing maize. These authors have found that intercropping was promising in weed control.

Several studies have shown that intercropping reduces wealth, infestation, density and growth of weeds in relation to monocropping (Ibeawuchi et al., 2005; Agegnehu et al., 2008; Nelson et al., 2012). In some of these studies, intercropping has provided economic benefit and weed control (Agegnehu et al., 2008). In others, there was a reduction of the infestation, but there was no benefit of intercropping in relation to monocropping (Nelson et al., 2012). Ibeawuchi et al. (2005) have found that the most productive intercroppings were the ones that least controlled weeds and vice versa. Finally, some intercroppings were less productive and have not controlled the weeds (Gomes et al., 2007).

Usually the control of weeds in maize is done with two hoeings. The hypothesis that motivated this study was that it would be advantageous to combine one of the two hoeings by intercropping with gliricidia, making this control in an integrated manner. Intercropping is established in less time, more easily and at lower cost than performing a hoeing. The integrated weed management (IWM) is a comprehensive process that combines direct and indirect strategies for weed control. IWM is a holistic approach to weed management that integrates different control methods to provide advantage of crops for weeds
(Harker \& O'Donovan, 2013). IWM promising results have been obtained by various authors (Olorunmaiye \& Olorunmaiye, 2009, for example).

The aim of this work was to study the effects of intercropping combination of gliricidia with doing hoeing on weed control and maize yield.

\section{MATERIALS AND METHODS}

The experiment has taken place on the farm Fazenda Experimental (latitude $5^{\circ} 11^{\prime} \mathrm{S}$, longitude $37^{\circ} 20^{\prime} \mathrm{W}$ and altitude $18 \mathrm{~m}$ ), during the period from May to September 2012. According to the Gaussen bioclimatic classification, the climate of the area is hot tropical, markedly dry with a dry season of seven to eight months. The region has the highest average air temperature between 32.1 and $34.5{ }^{\circ} \mathrm{C}$, and the minimum average between 21.3 and $23.7^{\circ} \mathrm{C}$, and June and July are the coldest months; the average annual rainfall is $825 \mathrm{~mm}$. Heat stroke increases from March to October, with an average of $241.7 \mathrm{~h}$. The maximum relative humidity of air reaches $78 \%$ in April, and the minimum, $60 \%$ in September.

The chemical analysis of the soil of the experimental area, classified as Alfisol (Embrapa, 2006), has shown: $\mathrm{pH}$ (water) = 6.46; organic matter $=8.36 \mathrm{~g} \mathrm{~kg}^{-1} ; \mathrm{P}=6.4 \mathrm{mg} \mathrm{dm}^{-3}$; $\mathrm{K}^{+}=81.3 \mathrm{mg} \mathrm{dm}^{-3} ; \mathrm{Na}=69.4 \mathrm{mg} \mathrm{dm}^{-3} ; \mathrm{Ca}^{2+}=$ $1.85 \mathrm{cmol}_{\mathrm{c}} \mathrm{dm}^{-3} ; \mathrm{Mg}^{2+}=0.80 \mathrm{cmol}_{\mathrm{c}} \mathrm{dm}^{-3}$; $\mathrm{Al}^{3+}=0.00 \mathrm{cmol}_{\mathrm{c}} \mathrm{dm}^{-3} ; \mathrm{H}+\mathrm{Al}=0.00 \mathrm{cmol}_{\mathrm{c}} \mathrm{dm}^{-3}$; $\mathrm{SB}=3.16 \mathrm{cmol}_{\mathrm{c}} \mathrm{dm}^{-3}$; PST (Phytoavailability Soil Test) $=10 \%$.

The soil was prepared with two harrowings and fertilized with $40 \mathrm{~kg} \mathrm{~N} \mathrm{ha}^{-1}$ (ammonium sulfate), $100 \mathrm{~kg}$ of $\mathrm{P}_{2} \mathrm{O}_{5}$ ha $^{-1}$ (single superphosphate) and $50 \mathrm{~kg} \mathrm{~K}_{2} \mathrm{O} \mathrm{ha}^{-1}$ (potassium chloride). The fertilizers were manually applied in furrows located next to and below the sowing furrows. Topdressing fertilization was performed at 20 and 40 days after sowing, with $40 \mathrm{~kg}$ of $\mathrm{N} \mathrm{ha}^{-1}$ (ammonium sulfate). The maize seeding was manually done on $05 / 21 / 2012$, using four seeds per hole, spaced $1.0 \times 0.4 \mathrm{~m}$. At 20 days after sowing, thinning was carried out, leaving the two largest plants in each pit, resulting in a programmed plant density of 
50,000 plants $\mathrm{ha}^{-1}$. The control of Fall Armyworm (Spodoptera frugiperda) was done with deltamethrin sprays at 10,20,30, 38 and 45 days after sowing.

The experiment was carried out under sprinkler irrigation. The daily water depth demanded for maize $(5.6 \mathrm{~mm})$ was calculated considering as being $0.40 \mathrm{~m}$ the effective depth of the root system. Irrigation time was based on the water held in the soil at the tension of $0.40 \mathrm{MPa}$. The irrigation interval was two days, with three weekly applications. Irrigation was initiated after planting and suspended 15 days before the maize harvest.

The randomized complete blocks design was used, with split plots and four replications. The experimental units comprised four rows of maize plants, $6 \mathrm{~m}$ long. As floor area, the one occupied by the two central rows was considered, discarding the plants of a pit on the edge of the central rows. Hybrids AG 1051 and BR 205 applied to the plots were subjected to the following treatments: two hoeings (at 20 and 40 days after sowing maize - DASM); sowing of gliricidia at the time of sowing maize + performing one hoeing at 40 DASM; performing one hoeing at 20 DASM + sowing gliricidia after the completion of the hoeing; sowing of gliricidia at the time of sowing maize; and no hoeing. The seeding of gliricidia was performed by broadcast seeding with 30 seeds $\mathrm{m}^{-2}$ and incorporation of the seeds with the aid of a rake.

The weeds were collected at 20, 40 (when the hoeings were performed) and 105 days after sowing maize in an area of $1.0 \times 0.8 \mathrm{~m}$, between the two rows of floor area of the experimental unit. The plants were cut close to the ground, identified, weighed and crushed. From the ground material, a sample of approximately $200 \mathrm{~g}$ was taken to the oven for assessment of the dry matter. After the botanical identification, the rate of occurrence of weeds was calculated (ratio between the number of plots in which a certain species of weed had occurred and the total number of experimental units).

Gliricidia was assessed in the following periods: 40 days after sowing (DAS), time of completion of the second hoeing; at 80 days DAS, period of performing the first hoeing; and at 100 days after sowing. The number of plants $\mathrm{m}^{-2}$, plant height, root collar diameter and shoot fresh and dry matters were assessed. The number of plants was estimated as an area of $5.2 \mathrm{~m}^{2}$, established in the central area between the two rows of maize plants floor area. Plant height was obtained with a ruler, and the root collar diameter with a caliper. The shoot fresh and dry matters were assessed in a similar manner as in the weeds.

The harvest of ripe ears was performed when the grains had water content of about $20 \%$ at 124 days after sowing. At the time of the harvest of the ripe ears, were assessed the plant and ear insertion heights, culm diameter, number of tassel branches, the total number of ears ha-1, the number of grains per ear, the mass of 100 grains and grain yield. Plant and ear insertion heights were measured in the floor area plants of each experimental unit. Plant height was regarded as the distance from the ground level to the insertion point of the highest leaf blade. The ear insertion height was measured from the ground level to the base of the highest ear. Culm diameter was measured at approximately $10 \mathrm{~cm}$ from the ground level, for the same plants used for the assessment of plant height, using a digital caliper. The number of tassel branches was obtained with an average of 10 tassels collected at random from the subplot. The number of grains per ear was obtained from 10 ears taken at random by multiplying the number of kernel rows by the number of kernels per row. The mass of 100 grains was estimated based on the mass of grains of the ears to assess the number of grains. Grain yield was corrected (wet basis) for a $15 \%$ moisture content.

The fresh and dry matters of shoots of maize plants were also assessed. After harvest, two plants in different pits were randomly collected, which were cut close to the ground. After weighing, the plants were ground and the dry matter was determined in a similar manner as in the assessment of the dry matter of gliricidia and weeds.

Data were subjected to analysis of variance and means compared to $5 \%$ probability by Tukey test, using software SAEG (Ribeiro Júnior, 2001). Data resulting from quantitative treatments were also subjected 
to a regression analysis using software Table Curve (Jandel Scientific, 1992).

\section{RESULTS AND DISCUSSION}

Forty-one species of weed infested the experimental area, considering the three sampling times (Table 1). Some aspects are noteworthy in this table data. Firstly, some species were not found in all three samples. In the first sampling, $51 \%$ of the species observed in the experiment were not observed in the experimental plots. In the second and third samples, $51 \%$ and $29 \%$, respectively, of the 41 species were not detected in the experiment.

Secondly, few species were predominant (Table 1). In the first sampling were more common (occurrence index greater than 50\%) the species Cenchrus echinatus, Ipomoea bahiensis, Malachra fasciata, Sida cordifolia and Trianthema portulacastrum. In the second sample, the most common species were Adenocalymma sp., C. echinatus, Digitaria sp. and Ipomoea bahiensis. In the third sample, the most frequently observed species were Adenocalymma sp., C. echinatus and Ipomoea bahiensis. The predominance of a few species is in agreement with Buhler (1999). According to this author, the weed population in a given area depends on several factors, and although the population comprises several species, few of them are prevalent, accounting for $70 \%$ to $90 \%$ of all species.

The third aspect that should be highlighted in the data in Table 1 is that some species that did not occur or occurred at low rates in the first sampling began to occur in

Table 1 - Occurrence index of weed species during the first and second hoeings (20 and 40 days after sowing maize) and in the end of the experiment

\begin{tabular}{|c|c|c|c|c|c|c|c|}
\hline \multirow{3}{*}{ Species name } & \multicolumn{3}{|c|}{$\begin{array}{c}\text { Samplings } \\
\text { (days after sowing maize) }\end{array}$} & \multirow{3}{*}{ Species name } & \multicolumn{3}{|c|}{$\begin{array}{c}\text { Samplings } \\
\text { (days after sowing maize) }\end{array}$} \\
\hline & 20 & 40 & 105 & & 20 & 40 & 105 \\
\hline & \multicolumn{3}{|c|}{ Occurrence index (\%) } & & \multicolumn{3}{|c|}{ Occurrence index $(\%)^{\frac{1}{}}$} \\
\hline Acanthospermum hispidum & 0 & 0 & 3 & Malachra fasciata & 60 & 0 & 0 \\
\hline Adenocalymna sp. & 44 & 81 & 65 & Malvaceae sp. & 0 & 6 & 0 \\
\hline Alternanthera tenella & 44 & 37 & 25 & Merremia cissoides & 6 & 0 & 0 \\
\hline Amaranthus viridis & 31 & 19 & 10 & Mimosa candollei & 6 & 0 & 7 \\
\hline Boerhavia diffusa & 0 & 0 & 2 & Mollugo verticillata & 12 & 25 & 2 \\
\hline Borreria verticillata & 6 & 0 & 50 & Neojobertia candolleana & 0 & 0 & 10 \\
\hline Cajanus canja & 0 & 0 & 2 & Panicum maximum & 0 & 6 & 0 \\
\hline Cenchrus echinatus & 100 & 100 & 90 & Pavonia cancellata & 0 & 0 & 2 \\
\hline Centrosema pascuorum & 19 & 0 & 0 & Phyllanthus amarus & 0 & 12 & 5 \\
\hline Chamaesyce hyssopifolia & 31 & 0 & 0 & Phyllanthus niruri & 37 & 0 & 0 \\
\hline Commelina benghalensis & 25 & 31 & 15 & Physalis angulata & 0 & 0 & 5 \\
\hline Corchorus hirtus & 0 & 31 & 17 & Portulaca oleracea & 0 & 50 & 7 \\
\hline Cucumis anguria & 12 & 0 & 7 & Richardia grandiflora & 0 & 0 & 32 \\
\hline Dactyloctenium aegyptium & 0 & 12 & 40 & Senna obtusifolia & 19 & 19 & 2 \\
\hline Digitaria sp. & 0 & 69 & 52 & Senna occidentalis & 0 & 0 & 2 \\
\hline Eragrostis sp. & 0 & 6 & 5 & Sida cordifolia & 56 & 19 & 2 \\
\hline Euphorbia heterophylla & 0 & 12 & 10 & Solanum agrarium & 0 & 31 & 0 \\
\hline Euphorbia hirta & 0 & 0 & 2 & Talinum paniculatum & 37 & 0 & 0 \\
\hline Herissantia crispa & 0 & 6 & 0 & Trianthema portulacastrum & 60 & 0 & 0 \\
\hline Indigofera hirsuta & 0 & 0 & 27 & Turnera subulata & 6 & 0 & 0 \\
\hline Ipomoea bahiensis & 75 & 75 & 55 & - & - & - & - \\
\hline
\end{tabular}

${ }^{1 /}$ Occurrence index = relationship between the number of experimental units in which certain species have occurred and the total number of experimental units of the experiment. 
the later sampling and vice versa. Some species, however, occurred in relatively high occurrence rates in all samples (C. echinatus, for example) and others in relatively low rates in all samples (Boerhavia difusa, for example). Many variables are involved in the findings shown in the data of Table 1 , including a non-random distribution of the species in the field, sampling difficulties, differences in germination, cycle, numbness, competitive ability and resistance of weed species to the control methods used (Marques et al., 2011; Borgy et al., 2012).

There was no effect of hybrids in the growth of weeds, assessed by the fresh and dry matters of shoot at 20 and 40 days after sowing (DAS) and at 105 DAS, although some authors have found differences in the competitive ability of maize cultivars with weeds (Williams II et al., 2006). The means of the shoot matters of weeds that have occurred in the plots of the two hybrids are presented in Table 2.

As expected, there was no effect of the weed control methods (the two treatments that included one hoeing at 20 days after sowing), in the sampling performed at 20 days after sowing, for the fresh and dry matters of the weeds. In the other sampling dates, there was effect of weed control methods on the growth of these plants. In the sampling carried out at 40 days after sowing, the treatment "intercropping with gliricidia at the time of sowing maize + hoeing at 40 days after sowing" led to higher yields of fresh and dry matters of shoots of weeds than the treatment that included two hoeings (Table 2), which occurred because in the treatment involving two hoeings the first one eliminated the weeds that had occurred up to 20 days after sowing. At 105 days after sowing, the absence of hoeings and intercropping with gliricidia, established at the time of sowing maize, allowed greater weed growth than the other treatments, which did not differ (Table 2).

The number of gliricidia plants was reduced for a longer period of coexistence with the weeds and maize (Table 3 ). The gliricidia plants that survived showed, however, a larger mass of fresh and dry matter of shoots and root collar diameter, depending on the time (Table 3). These comments were made on the basis of the adjusted regression equations, but the equations should be considered with caution because gliricidia, in the treatments it was included, was not sowed at the same time. There must be great genetic variability among gliricidia plants, and the plants that survived should be more tolerant to the competition with maize and weeds. The competitive ability of a species has two mechanisms: suppressive ability (SA)

Table 2 - Averages of shoot fresh and dry matter of weeds in response to weed control ${ }^{1 /}$

\begin{tabular}{|c|c|c|c|c|c|c|}
\hline \multirow{4}{*}{$\begin{array}{l}\text { Control methods } \\
\text { for weeds }\end{array}$} & \multicolumn{6}{|c|}{ Sampling dates (days after sowing maize) } \\
\hline & \multicolumn{2}{|c|}{20} & \multicolumn{2}{|c|}{40} & \multicolumn{2}{|c|}{105} \\
\hline & Fresh matter & Dry matter & Fresh matter & Dry matter & Fresh matter & Dry matter \\
\hline & \multicolumn{6}{|c|}{$\left(\mathrm{kg} \mathrm{ha}^{-1}\right)$} \\
\hline $\begin{array}{l}\text { Hoeings at } 20 \text { and } 40 \text { days } \\
\text { after sowing maize (DASM) }\end{array}$ & 8,735 a & $2,418 \mathrm{a}$ & $2,984 \mathrm{~b}$ & $481 \mathrm{~b}$ & $1,660 \mathrm{~b}$ & $353 \mathrm{~b}$ \\
\hline $\begin{array}{l}\text { Hoeing at } 20 \text { DASM + } \\
\text { intercropping with gliricidia } \\
\text { after hoeing }\end{array}$ & $5,086 \mathrm{a}$ & $1,317 \mathrm{a}$ & - & - & $6,941 \mathrm{~b}$ & $1,545 \mathrm{~b}$ \\
\hline $\begin{array}{l}\text { Intercropping with gliricidia } \\
\text { at the time of sowing maize } \\
+ \text { hoeing at } 40 \text { DASM }\end{array}$ & - & - & 32,362 a & 5,549 a & $4,376 \mathrm{~b}$ & $828 \mathrm{~b}$ \\
\hline $\begin{array}{l}\text { Intercropping with gliricidia } \\
\text { at the time of sowing maize }\end{array}$ & - & - & - & - & 16,682 a & 4,181 a \\
\hline Without hoeings & - & - & - & - & $15,925 \mathrm{a}$ & $3,557 \mathrm{a}$ \\
\hline Average of hybrids & 6411 & 1868 & 17673 & 3016 & 9117 & 2093 \\
\hline CV & 104 & 99.9 & 29.7 & 32.2 & 34.2 & 32.9 \\
\hline $\mathrm{CV}_{\text {Subplot }}(\%)$ & 57.8 & 52.3 & 44.3 & 43.1 & 47.1 & 42.1 \\
\hline
\end{tabular}

1/ Averages followed by the same letter do not differ at $5 \%$ probability by Tukey test. 
Table 3 - Averages of characteristics of gliricidia, intercropped with maize hybrids for weed control ${ }^{1 /}$

\begin{tabular}{|c|c|c|c|c|c|}
\hline $\begin{array}{l}\text { Control methods } \\
\text { for weeds }\end{array}$ & $\begin{array}{l}\text { Coexistence } \\
\text { periods with } \\
\text { maize and } \\
\text { weeds } \\
\text { (DASM, x) }\end{array}$ & $\begin{array}{l}\text { Number of } \\
\text { plants per } \mathrm{m}^{2} \\
\text { (y) }\end{array}$ & $\begin{array}{l}\text { Diameter of } \\
\text { the root collar } \\
\quad(\mathrm{y}, \mathrm{mm})\end{array}$ & $\begin{array}{l}\text { Fresh matter } \\
\left(\mathrm{y}, \mathrm{kg} \mathrm{ha}^{-1}\right)\end{array}$ & $\begin{array}{l}\text { Dry matter } \\
\left(\mathrm{y}, \mathrm{kg} \mathrm{ha}^{-1}\right)\end{array}$ \\
\hline $\begin{array}{l}\text { Intercropping with gliricidia at } \\
\text { the moment of sowing maize }+ \\
\text { hoeing at } 40 \text { days DASM }\end{array}$ & 40 & 17 & 3.26 & 574 & 79 \\
\hline $\begin{array}{l}\text { Hoeing at } 20 \text { DASM + intercropping } \\
\text { with gliricidia after hoeing }\end{array}$ & 80 & 16 & 4.98 & 637 & 160 \\
\hline $\begin{array}{l}\text { Intercropping with gliricidia at the } \\
\text { time of sowing maize }\end{array}$ & 100 & 10 & 5.81 & 606 & 157 \\
\hline \multicolumn{6}{|c|}{ Regression equations relating coexistence periods with maize and weeds (x) and characteristics of gliricidia (y) } \\
\hline Number of plants per $\mathrm{m}^{2}(\mathrm{y})$ & \multicolumn{5}{|c|}{$\mathrm{y}=29.82-1.83 \mathrm{x}^{0.5}, R^{2}=0.95$} \\
\hline Diameter of the root collar $(\mathrm{y}, \mathrm{mm})$ & \multicolumn{5}{|c|}{$\mathrm{y}=-0.097+0.571 \mathrm{x}^{0.5}, R^{2}=0.99$} \\
\hline Fresh matter $\left(\mathrm{y}, \mathrm{kg} \mathrm{ha}^{-1}\right)$ & \multicolumn{5}{|c|}{$\mathrm{y}=-0.22-0.50 \mathrm{x}^{1.5}+111.18 \mathrm{x}^{0.5}, R^{2}=0.99$} \\
\hline Dry matter $\left(\mathrm{y}, \mathrm{kg} \mathrm{ha}^{-1}\right)$ & \multicolumn{5}{|c|}{$\mathrm{y}^{0.5}=-0.2050+0.2940 \mathrm{x}-0.0017 \mathrm{x}^{2}, R^{2}=0.99$} \\
\hline \multicolumn{2}{|l|}{ Averages of hybrids } & 14.0 & 4.69 & 606 & 132 \\
\hline \multicolumn{2}{|l|}{$\mathrm{CV}_{\text {plot }}(\%)$} & 47.1 & 7.1 & 67.5 & 78.7 \\
\hline \multicolumn{2}{|l|}{$\mathrm{CV}_{\text {Subplot }}(\%)$} & 33.7 & 15.6 & 43.5 & 52.1 \\
\hline
\end{tabular}

1/ DASM = days after sowing maize. The parameters of all equations are significant at $5 \%$ probability by the $t$ test.

and tolerance. SA is the ability of the species to inhibit the germination, growth or reproduction of one or other species. Tolerance allows the species to survive and yield under the stress of competition with other species (Jordan, 1993). Better SA can provide a reduction in the pressure of other species and their seed bank. However, the tolerance can allow the seed bank increase of other species (Williams II et al., 2006).

In the gliricidia plant height, there was an effect of hybrids (H), weed control (C) and the interaction $\mathrm{H} \times \mathrm{C}$. The hybrids did not influence the gliricidia plant height in the first two samples, but in the end of the cycle it presented greater plant height when intercropped with hybrid BR 205 (Table 4). Therefore, the influence of maize on gliricidia plant height has occurred as the legume cycle progressed. The highest hybrid AG 1051 plant height must have contributed to reduce the legume plant height (Table 4). Zystro et al. (2012) have concluded that from a number of characteristics of maize plant height was more predictive of the suppressive ability and maize tolerance capability in relation to weeds. It should be noted that, at least in the early growth stages, gliricidia must face increased competition from weeds than maize because it was planted between the rows of this one, where the occurrence of weeds is greater. Gliricidia must face increased competition from maize as the grass grows and "closes" the space between the rows of crop.

There was an effect of weed control methods $(\mathrm{M})$ in plant height and ear insertion height, the culm diameter and the number of tassel branches and the fresh and dry matters of shoots of maize. From these characteristics, there was an effect of hybrids $(\mathrm{H})$ only in plant height and ear insertion height and number of tassel branches. In none of these traits there was effect of $\mathrm{M} \mathrm{x} \mathrm{H}$. interaction.

Hybrid AG 1051 showed the highest plant height and ear insertion height and number of tassel branches lower than hybrid BR 205 (Table 5). The highest plant height and ear insertion height, fresh and dry matters of shoots of plants obtained after collection of the ears and the largest culm diameter and number of tassel branches were obtained with the performance of two hoeings (Table 5). The second best treatment for weed control was 
Table 4 - Averages of gliricidia of plant height, after periods of coexistence with the and weeds ${ }^{\underline{1}}$

\begin{tabular}{|c|c|c|c|}
\hline \multirow{5}{*}{ Hybrids } & \multicolumn{3}{|c|}{ Control methods of weeds } \\
\hline & $\begin{array}{c}\text { Intercropping with gliricidia at the time } \\
\text { of sowing } \\
\text { maize + hoeing at } 40 \text { DASM }\end{array}$ & $\begin{array}{l}\text { Hoeing at } 20 \text { DASM + } \\
\text { intercropping with gliricidia } \\
\text { after hoeing }\end{array}$ & $\begin{array}{l}\text { Intercropping with gliricidia at the } \\
\text { time of sowing maize }\end{array}$ \\
\hline & \multicolumn{3}{|c|}{$\begin{array}{l}\text { Coexistence periods with maize and weeds } \\
\text { (x, days after sowing maize) }\end{array}$} \\
\hline & 40 & 80 & 100 \\
\hline & \multicolumn{3}{|c|}{ Height of the plant $(\mathrm{y}, \mathrm{cm})$} \\
\hline AG 1051 & $19.3 \mathrm{a}$ & $23.5 \mathrm{a}$ & $26.0 \mathrm{~b}$ \\
\hline BR 205 & $19.8 \mathrm{a}$ & $25.8 \mathrm{a}$ & $34.0 \mathrm{a}$ \\
\hline \multicolumn{4}{|c|}{ Regression equations, $R^{2}$} \\
\hline AG 1051 & $\mathrm{y}=0.71+2.61 \mathrm{x}^{0.5}, R^{2}=0.98$ & & \\
\hline BR 205 & $\mathrm{y}=-0.31+3.20 \mathrm{x}^{0.5}, R^{2}=0.98$ & & \\
\hline
\end{tabular}

$1 /$ DASM = days after sowing maize. Means followed by the same letter in columns do not differ at $5 \%$ probability by Tukey test.

Table 5 - Averages of the heights of plant and ear insertion, culm diameter and number of branches of the tassel and fresh and dry matter of maize in response to weed control. Mossoró, RN. UFERSA, 2012¹

\begin{tabular}{|c|c|c|c|c|c|c|}
\hline $\begin{array}{l}\text { Control methods } \\
\text { for weeds }\end{array}$ & $\begin{array}{l}\text { Height of the } \\
\text { plant }(\mathrm{cm})\end{array}$ & $\begin{array}{l}\text { Height of ear } \\
\text { insertion } \\
(\mathrm{cm})\end{array}$ & $\begin{array}{l}\text { Diameter of } \\
\text { the culm } \\
(\mathrm{mm})\end{array}$ & 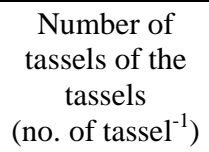 & $\begin{array}{l}\text { Fresh matter } \\
\text { of the plant } \\
\left(\mathrm{kg} \mathrm{ha}^{-1}\right)\end{array}$ & $\begin{array}{l}\text { Dry matter of } \\
\text { the plant } \\
\left(\mathrm{kg} \mathrm{ha}^{-1}\right)\end{array}$ \\
\hline $\begin{array}{l}\text { Hoeings at } 20 \text { and } 40 \\
\text { days after sowing maize } \\
\text { (DASM) }\end{array}$ & $175.05 \mathrm{a}$ & $95.40 \mathrm{a}$ & $21.24 \mathrm{a}$ & $17 \mathrm{a}$ & 24,828 a & 6,144 a \\
\hline $\begin{array}{l}\text { Hoeing at } 20 \text { DASM + } \\
\text { intercropping with } \\
\text { gliricidia after hoeing }\end{array}$ & $176.16 \mathrm{a}$ & $95.94 \mathrm{a}$ & 20.99 a & $15 \mathrm{ab}$ & $23,109 a b$ & $5,626 \mathrm{ab}$ \\
\hline $\begin{array}{l}\text { Intercropping with } \\
\text { gliricidia at the time of } \\
\text { sowing maize + hoeing } \\
\text { at } 40 \text { DASM }\end{array}$ & $153.21 \mathrm{~b}$ & $78.04 \mathrm{~b}$ & $15.55 \mathrm{~b}$ & $13 \mathrm{bc}$ & 17,813 bc & 4,347 bc \\
\hline $\begin{array}{l}\text { Intercropping with } \\
\text { gliricidia at the time of } \\
\text { sowing maize }\end{array}$ & $166.82 a b$ & 90.96 a & $16.20 \mathrm{~b}$ & $13 \mathrm{bc}$ & 18,766 bc & 4,450 bc \\
\hline Without hoeings & $167.65 \mathrm{a}$ & $91.52 \mathrm{a}$ & $16.81 \mathrm{~b}$ & $12 \mathrm{c}$ & $15,453 \mathrm{c}$ & $3,839 \mathrm{c}$ \\
\hline \multicolumn{7}{|c|}{ Cultivars } \\
\hline AG 1051 & $176 \mathrm{a}$ & $100 \mathrm{a}$ & $18.3 \mathrm{a}$ & $13 \mathrm{~b}$ & $21,388 \mathrm{a}$ & $5,121 \mathrm{a}$ \\
\hline BR 205 & $160 \mathrm{~b}$ & $80 \mathrm{~b}$ & $18.0 \mathrm{a}$ & $15 \mathrm{a}$ & $18,600 \mathrm{a}$ & $4,642 \mathrm{a}$ \\
\hline $\mathrm{CV}_{\text {plot }}(\%)$ & 8.2 & 11.7 & 7.1 & 4.7 & 255 & 33.7 \\
\hline $\mathrm{CV}_{\text {Subplot }}(\%)$ & 5.6 & 8.5 & 8.3 & 13.5 & 20.1 & 21.5 \\
\hline
\end{tabular}

1/ Averages followed by the same letter do not differ at $5 \%$ probability by Tukey test.

represented by the combination of a hoeing performed at 20 days after sowing by intercropping with gliricidia after this hoeing (Table 5), except for plant height and ear insertion height, in which the absence of hoeing and intercropping with gliricidia at the time of sowing maize yielded averages that did not differ in means from the best treatments (Table 5). Plant height and ear insertion height and culm diameter were assessed because they are features often associated to lodging of maize (Echezona, 2007), but in this study there was no lodging, confirming that this is not a problem for the region. The number of 
tassel branches was assessed because it can give a negative correlation with maize yield (Farias Neto \& Miranda Filho, 2001).

There was an effect of hybrids (H) only on the mass of 100 grains, but the control methods of weeds (M) influenced the grain yield and its components, except the mass of 100 grains. There was no effect of $\mathrm{H} \mathrm{x} \mathrm{M}$ interaction on grain yield and its components.

Hybrid AG 1051 was greater than hybrid BR 205 regarding the mass of 100 grains (Table 6). The intercropping with gliricidia at the time of sowing maize + hoeing at 40 days after sowing maize made possible the largest number of ears per hectare, and the performance of two hoeings gave the highest grain yield and number of grains per ear. The second best treatment regarding the number of ripe ears per hectare, number of grains per ear and grain yield was always the performance of one hoeing at 20 days after sowing maize + intercropping with gliricidia after hoeing (Table 6). Intercropping with gliricidia, established at the time of sowing maize, was higher than the absence of hoeings regarding these features, again indicating that gliricidia partially controls the weeds of maize.
The weeds have reduced growth (Table 5) and grain yield (Table 6) of maize. Weeds reduce crop yields by competing with them for water, nutrients and light. In this competition various processes are involved above and below the soil surface.

Intercropping maize with gliricidia from the maize sowing was beneficial for maize, because in the mass of 100 grains and the number of grains per ear (Table 6) the averages obtained with intercropping were higher than those obtained in the absence of hoeing, indicating that gliricidia partially controlled the weeds. This control must have been by means of the competition for water, light, nutrients and space, as well as allelopathy (Oyun, 2006).

The combination of hoeing with intercropping with gliricidia brought more benefits for maize than intercropping isolated with this crop. This combination has been overcome, but in some instances it was equivalent to the performance of two hoeings with regard to grain yield (Table 6). In 10 cases in which the Tukey test was applied to maize yields or characteristics related to it (Tables 5 and 6), the implementation of hoeing at 20 days after sowing maize (DASM) +

Table 6 - Averages of number of grains per ear, number of ears per hectare, mass of 100 grains and maize grain yield in response to weed control ${ }^{1 /}$

\begin{tabular}{|c|c|c|c|c|}
\hline Control methods for weeds & $\begin{array}{l}\text { Number of } \\
\text { grains per ear }\end{array}$ & $\begin{array}{l}\text { Number of ears } \\
\text { per hectare }\end{array}$ & $\begin{array}{l}\text { Matter of } 100 \\
\text { grains } \\
\text { (g) }\end{array}$ & $\begin{array}{l}\text { Yield of grains } \\
\qquad\left(\mathrm{kg} \mathrm{ha}^{-1}\right)\end{array}$ \\
\hline $\begin{array}{l}\text { Hoeings at } 20 \text { and } 40 \text { days after sowing maize } \\
\text { (DASM) }\end{array}$ & $524 \mathrm{a}$ & $49,740 \mathrm{ab}$ & $28.62 \mathrm{a}$ & 7,728 a \\
\hline $\begin{array}{l}\text { Hoeing at } 20 \text { DASM + intercropping with } \\
\text { gliricidia after hoeing }\end{array}$ & $510 \mathrm{ab}$ & $48,487 \mathrm{ab}$ & 30.16 a & 7,527 ab \\
\hline $\begin{array}{l}\text { Intercropping with gliricidia at the time of } \\
\text { sowing maize + hoeing at } 40 \text { DASM }\end{array}$ & 464 bc & 50,270 a & 29.82 a & 6,722 bc \\
\hline $\begin{array}{l}\text { Intercropping with gliricidia at the time of } \\
\text { sowing maize }\end{array}$ & 453 bc & $49,259 a b$ & 29.05 a & 6,085 bc \\
\hline Without hoeings & $434 \mathrm{c}$ & $47,827 \mathrm{~b}$ & $27.66 \mathrm{a}$ & $5,758 \mathrm{c}$ \\
\hline \multicolumn{5}{|c|}{ Cultivars } \\
\hline AG 1051 & $471 \mathrm{a}$ & 49,131 a & $30.1 \mathrm{a}$ & $6,841 \mathrm{a}$ \\
\hline BR 205 & $483 \mathrm{a}$ & 49,102 a & $28.1 \mathrm{~b}$ & $6,687 \mathrm{a}$ \\
\hline $\mathrm{CV}_{\text {plot }}(\%)$ & 15.7 & 4.8 & 5.0 & 17.9 \\
\hline $\mathrm{CV}_{\text {Subplot }}(\%)$ & 9.2 & 3.2 & 9.2 & 15.9 \\
\hline
\end{tabular}

1/ Averages followed by the same letter do not differ at $5 \%$ probability by Tukey test. 
intercropping with gliricidia after completion of this hoeing was higher in eight to intercropping treatment with gliricidia at the time of the maize sowing + hoeing at 40 DASM. In only one case (Table 6) the opposite occurred, and in only one case the two treatments were similar (Table 6).

The superiority, for most of the assessed characteristics, of the treatment "performance of hoeing at 20 days after sowing maize $(\mathrm{DASM})+$ intercropping with gliricidia after performing this hoeing", in relation to the other combination hoeing + intercropping studied in this work, in most of the assessed data (Tables 5 and 6) can be related to the socalled critical period of weed control (CPWC), minimum time period that the crop should be kept free of weeds to prevent unacceptable yield losses . Zimdahl (1981), in a review study, has concluded that CPWC ranged between 14 and 42 days after sowing. This period is justified because the performance of hoeing at 20 days after sowing maize (DASM) was generally more advantageous than the performance of hoeing at 40 DASM. However, as the hoeing made at 40 DASM is still included in CPWC, it eventually brought benefits to maize.

It was found in this study that hybrids were not different in the effects on the growth of weeds, or on the grain yield. The performance of two hoeings and the combination of one hoeing by intercropping with gliricidia have reduced the growth of weeds of maize, regarding the absence of hoeing and intercropping (without hoeing) with gliricidia. The highest grain yield was obtained with two hoeings, and the lowest in the absence of hoeing. Intercroppings with gliricidia have provided intermediate sized yields. The hoeing at 20 DASM + intercropping with gliricidia after hoeing gave higher grain yield than other intercroppings, which provided the same yields. The stand of gliricidia was reduced with the increase in the coexistence period with weeds and maize. It showed higher plant height when intercropped with hybrid BR 205.

It can be concluded that maize and gliricidia in intercropping, under the conditions assessed, is not a good alternative for an for integrated weed management in maize crops.

\section{LITERATURE CITED}

AGEGNEHU, G.; GHIZAW, A.; SINEBO, W. Yield potential and land-use efficiency of wheat and faba bean mixed intercropping. Agron. Sustain. Dev., v. 28, n. 2, p. 257-263, 2008.

BORGY, B. et al. Non-random distribution of weed species abundance in arable fields. Weed Res., v. 52, n. 4, p. 383-389, 2012.

BUHLER, D. D. Weed population responses to weed control practices. I. Seed bank, weed populations, and crop yields. Weed Sci., v. 47, n. 4, p. 416-422, 1999.

CHIKOYE, D.; SCHULZ, S.; EKELEME, F. Evaluation of integrated weed management practices for maize in the northern Guinea savanna of Nigeria. Crop Protec., v. 23, n. 3, p. 895-900, 2004.

CHRISTOFFOLETI, P. J. (Coord.). Aspectos de resistência de plantas daninhas a herbicidas. Piracicaba: Associação Brasileira de Ação à Resistência de Plantas Daninhas, 2008. $120 \mathrm{p}$.

ECHEZONA, B. C. maize-stalk lodging and borer damage as influenced by varying maize densities and planting geometry with soybean (Glycine max L. Merrill). Inter. Agrophysics, v. 21, n. 2, p. 133-143, 2007.

EMPRESA BRASILEIRA DE PESQUISA AGROPECUÁRIA - EMBRAPA. Centro Nacional de Pesquisa do Solo. Sistema brasileiro de classificação de solos. 2. Ed. Brasília, 2006. 412 p.

FARIAS NETO, A. L.; MIRANDA FILHO, J. B. Genetic correlation between traits in the ESALQ-PB1 maize population divergently selected for tassel size and ear height. Sci. Agricola, v. 58, n. 1, p. 119-123, 2001.

GOMES, J. K. O. et al. Effects of weed control through cowpea intercropping on maize morphology and yield. Planta Daninha, v. 25, n. 3, p. 433-441, 2007.

HARKER, K. N.; O’DONOVAN, J. T. Recent weed control, weed management, and integrated weed management. Weed Technol., v. 27, n. 1, p. 1-11, 2013.

IBEAWUCHI, I. I.; OBIEFUNA, J. C.; OFOH, M. C. Effects of row spacing on yield and yield components of okra (Abelmoschus esculentus) and mixture groundnut (Arachis hypogaea). J. Agron., v. 4, n. 4, p. 304-307, 2005.

JANDEL SCIENTIFIC. Table Curve 3.0: curve fitting software. Corte Madera, 1992.

Planta Daninha, Viçosa-MG, v. 33, n. 2, p. 249-258, 2015 
JORDAN, N. Prospects for Weed control through crop interference. Ecol. Appl., v. 3, n. 1, p. 84-91, 1993.

MARQUES, L. J. P. et al. Dinâmica de populações e fitossociologia de plantas daninhas no cultivo do feijãocaupi e mandioca no sistema corte e queima com o uso de arado. Planta Daninha, v. 29, n. 1, p. 981-989, 2011.

MODEL, N. S.; FAVRETO, R. Comparação de custos de tratamentos de controle de plantas daninhas em abacaxizeiro cultivado no Rio Grande do Sul, Brasil. Pesq. Agropec. Gaúcha, v. 16, n. 1-2, p. 45-50, 2010.

NELSON, A. G. et al. Yield and weed suppression of crop mixtures in organic and conventional systems of the western Canadian prairie. Agron. J., v. 104, n. 3, p. 756-762, 2012.

OFOSU-ANIM, J.; LIMBANI, N. V. Effect of intercropping on the growth and yield of cucumber (Cucumis sativus L.) and okra (Abelmoschus esculentus L.). Int. J. Agric. Biol., v. 9, n. 4, p. 594-597, 2007.

OLIVEIRA JR., R. S.; CONSTANTIN, J.; INOUE; M. H. Biologia e manejo de plantas daninhas. (2. Ed.), Curitiba: Omnipax, 2011. 348 p.

OLORUNMAIYE, P. M.; OLORUNMAIYE, K. S. Effect of integrated weed management on weed control and yield components of maize and cassava intercrop in a southern Guinea savanna ecology of Nigeria. Aust. J. Crop Sci., v. 3, n. 3, p. 129-136, 2009.
OYUN, M. B. Allelopathic potentialities of Gliricidia sepium and Acacia auriculiformis on the germination and seedling vigour of maize (Zea mays L.). Am. J. Agric. Biol. Sci., v. 1, n. 3, p. 44-47, 2006.

PINHEIRO, A.; ROSA, F. C. Classificação dos pesticidas usados na Bacia Hidrográfica do Itajaí (SC) quanto ao risco de degradação dos recursos hídricos. Pesticidas: R. Ecotox.

Meio Amb., v. 18, n. 1, p. 45-58, 2008

RIBEIRO JR., J. I. Análise estatísticas no SAEG. Viçosa, Universidade federal de Viçosa, 2001. 301 p.

SILVA, D. V. et al. Manejo de plantas daninhas na cultura da mandioca. Planta Daninha, v. 30, n. 4, p. 901-910, 2012.

WILLIAMS II, M. M.; BOYDSTON, R. A.; DAVIS, A. S. Canopy variation among three sweet corn hybrids and implications for light competition. Hort. Sci., v. 41, n. 6, p. 1449-1454. 2006.

ZÁRATE, N. A. H. et al. Produção e renda líquida de milho verde em função da época de amontoa. Semina Ci. Agric., v. 30, n. 1, p. 95-100, 2009.

ZIMDAHL, R. L. The concept and application of the weedfree period. In: ALTIERI, M. A.; LIEBMAN, M. Weed management in agroecosystems: ecological approaches. New York: CRC Press, 1981. 368 p.

ZYSTRO, J. P.; LEON, N.; TRACY, W. F. Analysis of traits related to weed competitiveness in sweet corn (Zea mays L.). Sustainability, v. 4, n. 4, p. 543-560, 2012. 